\title{
Eksistensi Penerapan Ultimum Remedium dalam Sistem Hukum Pidana Indonesia
}

\author{
Sheila Maulida Fitri \\ Kementerian Pertahanan Republik Indonesia, Email: sheilamaulidaf@gmail.com
}

\begin{abstract}
Criminal Law in Indonesia which was ideally applied as the ultimate last weapon (ultimum remedium) in dealing with violations, has now shifted to become the main weapon (primum remedium). This is inseparable from the criminal law policy which is still oriented as a form of retaliation and punishment so that it prioritizes penal policies with a focus on imposing sanctions in the form of deprivation of liberty. Criminal law has always been used as the main weapon in solving various kinds of violations. This has led to a condition of overcriminalization which has created new problems at the applicative level. Reforming criminal law is considered very urgent to be carried out by accommodating a restorative justice approach in order to re-place criminal law as an ultimum remedium. First, the application of decriminalization policies in various laws and regulations in Indonesia. Second, the reorientation of the criminal procedural law system which gives the possibility of a criminal case settlement process out of court (afdoening buiten process).
\end{abstract}

Keyword: Criminal Law; Restorative Justice; Ultimum Remedium.

\section{PENDAHULUAN}

Kehidupan masyarakat berbangsa dan bernegara di Indonesia belakangan ini dinilai sangat dinamis. Seringkali dalam perjalanannya terdapat sekelompok orang atau oknum tertentu yang menimbulkan keresahan di masyarakat dengan melakukan pelanggaran hukum yang mengancam keamanan baik di tingkat regional maupun nasional baik dilakukan oleh individu maupun kelompok.

Badan Pusat Statistik (BPS) merilis angka statistik jumlah kejahatan yang terjadi di Indonesia, data tahun 2017 hingga 2019 memang menunjukan adanya kecenderungan penurunan kasus kejahatan yaitu pada tahun 2017 terdapat sebanyak 336.652 kejadian, menurun pada tahun 2018 menjadi 294.281 kejadian dan pada tahun 2019 menurun menjadi 269.324 kejadian. ${ }^{1}$ Meski mengalami penurunan, tidak dapat dipungkiri bahwa terdapat satu kondisi dimana di tengah-tengah masyarakat terjadi suatu tindak pidana namun tidak dilaporkan atas berbagai macam faktor atau pertimbangan baik dari para korban maupun masyarakat setempat. Selain kuantitas kejahatan, modus operandi kejahatan yang semakin berkembang juga perlu diwaspadai seiring dengan perkembangan sosial, ekonomi, dan teknologi.

Indonesia sebagai negara hukum sebagaimana ketentuan Pasal 1 ayat (3) UUD 1945, memiliki instrumen hukum dalam bidang hukum pidana yang merupakan salah satu

\footnotetext{
${ }^{1}$ Badan Pusat Statistik. (2020). Statistik Kriminal 2020, Hlm. 10 Diunduh Dari Https://Www.Bps.Go.Id/Publication/2020/11/17/0f2dfc46761281f68f11afb1/Statistik-Kriminal-2020.Html
} 
hukum positif yang memiliki peran penting dalam rangka menciptakan ketertiban dan keamanan bagi seluruh warga Indonesia. Hal ini merupakan tujuan umum hukum pidana yaitu guna melindungi kepentingan orang perseorangan atau hak asasi manusia dan masyarakat. Tujuan hukum pidana di Indonesia harus sesuai dengan falsafah Pancasila yang mampu membawa kepentingan yang adil bagi seluruh warga negara. ${ }^{2}$ Namun, sifat hukum pidana yang terkesan kejam dalam tataran aplikatif menjadikannya harus berpegang teguh pada prinsip Ultimum Remedium yaitu hukum pidana sebagai senjata pamungkas (terakhir) dalam penegakan hukum sehingga harus mengedepankan sanksi-sanksi hukum lainnya.

Penerapan sanksi hukum pidana saat ini dinilai cenderung lebih dikedepankan sehingga asas ultimum remedium seolah-olah bergeser, yang seharusnya sanksi pidana menjadi senjata pamungkas terakhir tapi kini justru cenderung menjadi senjata utama atau dikenal dengan istilah primum remedium dan mengesampingkan sanksi bidang hukum lainnya.

Banyak faktor yang mempengaruhi hal tersebut diantaranya minimnya pemahaman masyarakat dan/atau aparat penegak hukum bahwa ajaran hukum pidana dan penerapan sanksinya sesungguhnya bersifat subsider, pemahaman umum bahwa sanksi hukum pidanalah yang dirasa lebih memberikan efek jera meski terdapat alternatif penyelesaian sengketa dengan upaya kekeluargaan. Bahkan terhadap tindak pidana yang dinilai ringan sekalipun menerapkan sanksi hukuman badan. Padahal dalam sub sistem pemidanaan masih terdapat sanksi lain selain hukuman badan sebagaimana dalam ketentuan Pasal 10 KUHP selain itu juga karena adanya kecenderungan banyak peraturan-peraturan yang sifatnya administratif memasukan sanksi hukum pidana di dalamnya sebagai sanksi utama dalam penegakan pelanggarannya.

Salah satu contoh kecil dari sekian banyak aturan baik di dalam KUHP maupun dalam bidang hukum lainnya adalah pelanggaran terhadap norma di dalam UU ITE khususnya pada kasus pencemaran nama baik melalui teknologi informasi maupun secara konvensional, jika ditelaah lebih jauh sesungguhnya kasus semacam ini dapat diselesaikan secara hukum perdata. Hal ini dikarenakan proses terjadinya pencemaran nama baik adalah menyangkut hubungan person to person, pelaku adalah subjek yang melakukan perbuatan yang diduga mencederai nama baik subjek hukum yang lainnya. Penerapan sanksi perdata dalam kasus serupa diterapkan juga di Malaysia dan beberapa Negara lainnya dimana sanksinya berupa ganti kerugian. Itu hanya sedikit contoh kasus dari sekian banyak aturan yang dinilai tidak lagi relevan dengan kondisi hukum, sosial, politik dan ekonomi di masa kini. Alhasil, penerapan sanksi hukum pidana sebagai primum remidium menimbulkan berbagai masalah pada sistem penegakan hukum di Indonesia, misalnya overload capacity di rumah tahanan yang mengakibatkan terabaikannya kesejahteraan narapidana di dalamnya.

KUHP sebagai induk peraturan hukum pidana di Indonesia sudah sepatutnya menjadi ruh bagi undang-undang di luar KUHP namun kini dinilai sudah tidak relevan dengan sistem hukum pidana yang ideal dengan kondisi masyarakat di Indonesia.

\section{METODE PENELITIAN}

Metode penelitian yang digunakan adalah metode yuridis normatif dengan pendekatan peraturan perundang-undangan dan analitis, sedangkan pengumpulan data

\footnotetext{
${ }^{2}$ Teguh Prasetyo. (2010). Hukum Pidana. Jakarta: Rajawali Press, hlm 7.
} 
melalui studi kepustakaan dengan pendekatan konseptual untuk menjelaskan dan mengaitkan dengan teori-teori yang relevan. Sumber data dalam penelitian ini menggunakan sumber data sekunder yang didapat dari literatur dan sumber hukum primer, sekunder, serta tersier. Hasil penelitian dianalisis dan diuraikan secara deskriptif kualitatif.

\section{ANALISIS}

\section{Ultimum Remedium Dalam Ajaran Hukum Pidana}

Dalam ajaran hukum pidana dikenal sebuah asas ultimum remedium, sebagian orang berpendapat ultimum remedium sesungguhnya hanya sebuah istilah. Ultimum remedium berarti norma atau kaidah dalam bidang hukum lain seperti hukum tata negara dan hukum tata usaha negara harus diselesaikan dengan penggunaan sanksi administrasi, begitu pula norma-norma dalam bidang hukum perdata harus diutamakan diselesaikan dengan sanksi perdata. Namun, dalam hal sanksi administrasi dan sanksi perdata ini dinilai belum mencukupi untuk mencapai tujuan guna menciptakan ketertiban dan menyelesaikan permasalahan di masyarakat, maka baru digunakan sanksi pidana sebagai senjata pamungkas (terakhir). ${ }^{3}$ Dengan kata lain, ketika suatu perkara masih dapat diselesaikan melalui upaya hukum lain seperti cara kekeluargaan, negosiasi, mediasi, ataupun hukum administrasi maka hendaknya jalur tersebut terlebih dahulu dilalui sebelum memutuskan menempuh penyelesaian hukum secara pidana.

Hal ini bukan tanpa alasan, hukum pidana memang memiliki sejarah yang kelam, Van Hamel menyatakan bahwa arti dari pidana atau Straf menurut hukum positif adalah suatu penderitaan yang bersifat khusus oleh yang telah dijatuhkan oleh kekuasaan yang berwenang untuk menjatuhkan pidana atas nama negara sebagai penanggung jawab dari ketertiban hukum umum bagi seorang pelanggar, yakni semata-mata karena orang tersebut telah melanggar suatu peraturan hukum yang harus ditegakkan oleh negara. ${ }^{4}$ Pemikiran para para tokoh masa lalu menempatkan tujuan pidana sebagai suatu penderitaan dan alat untuk mencapai penderitaan itu sendiri. Padahal Pidana di satu sisi tidak hanya dimaksudkan untuk memberikan penderitaan atau memberikan efek jera kepada pelanggar namun, di sisi lain juga untuk mempersiapkan pelanggar agar dapat kembali diterima dan hidup di masyarakat dengan layak. ${ }^{5}$

Sanksi hukum pidana yang sebagian besar diterapkan adalah sanksi perampasan kemerdekaan, jika tidak diterapkan dengan hati-hati maka berpotensi melanggar hakhak konstitusional warga negara. Atas dasar itu juga maka rentan terjadi penyalahgunaan jika tujuan pemidanaan adalah sebagai bentuk balas dendam. Oleh karena itu, tujuan pengenaan sanksi pidana dipengaruhi oleh alasan yang dijadikan dasar pengancaman dan penjatuhan pidana. Maka idealnya dalam konteks ini alasan pemidanaan selain sebagai pembalasan, namun juga harus memberikan kemanfaatan, serta gabungan antara pembalasan yang memiliki tujuan atau pembalasan yang diberikan kepada pelaku dengan maksud dan tujuan tertentu. ${ }^{6}$

\footnotetext{
3 Wirjono Prodjodikoro. (2003). Asas-Asas Hukum Pidana Di Indonesia”, Bandung: Refika Aditama. hlm. 17

${ }^{4}$ Tolib Setiady. (2010). Pokok-Pokok Hukum Panitensier Indonesia. Bandung; Alfabeta. hlm. 19

${ }^{5}$ P.A.F. Lamintang. (1984). Hukum Panitensier Indonesia. Bandung: Armico, Bandung. hlm 36

${ }^{6}$ Mudzakkir Dkk, Perencanaan Pembangunan Hukum Nasional Bidang Hukum Pidana Dan Sistem Pemidanaan (Politik Hukum Dan Pemidanaan), hlm. 10, diunduh pada Https://Www.Bphn.Go.Id/Data/Documents/Pphn_Bid_Polhuk\&Pemidanaan.Pdf .
} 


\section{Pergeseran Penerapan Hukum Pidana Menjadi Primum Remedium}

Sejarah penegakkan hukum pidana di Indonesia telah menunjukan bahwa sebagai negara hukum yang menganut Asas Legalitas, aparatur penegak hukum menerapkan Hukum Pidana secara berlebihan (overspanning van het straftrecht). Padahal, esensi Hukum Pidana adalah sebagai "senjata pamungkas atau senjata terakhir" (ultimum remedium).

Terdapat beberapa kasus yang menunjukan penerapan hukum pidana yang sesungguhnya tidak disertai dengan niat jahat (mens rea) dan/atau memenuhi unsur pasal namun dinilai tidak layak untuk dijatuhi pidana atau dengan kata lain masih bisa diselesaikan melalui sanksi hukum lainnya, kasus tersebut antara lain sebagai berikut:

a. Kasus Fidelis Arie Sudewarto, ia ditangkap oleh Badan Narkotika Nasional (BNN) karena menanam 39 batang pohon ganja untuk pengobatan kanker sumsum tilang belakang istrinya bukan untuk dikonsumsi sendiri sebagai pecandu, apalagi diedarkan. Sang istri pada akhirnya meninggal dunia 32 hari setelah Fidelis ditangkap BNN. Fidelis Arie Sudewarto dalam putusannya divonis bersalah dengan hukuman delapan bulan penjara dan denda Rp1 miliar subsider satu bulan dalam sidang putusan pada 2 Agustus 2017 . $^{7}$

b. Kasus Nenek Minah, Kasus Nenek Minah bermula ketika ia dituduh mencuri 3 biji kakao dari perkebunan milik PT. Rumpun Sari Antan (RSA) 4. Saat itu ia hanya bermaksud mengambil 3 biji buah kakao yang terjatuh dari pohonnya untuk dibawa pulang dan dijadikan benih di kebun kakao miliknya. Namun ia geletakkan kembali di tanah, belum sempat buah tersebut dibawa pulang, seorang mandor perkebunan, Nenek Minah lantas meminta maaf dan meminta Sutarno untuk membawa ketiga buah kakao tersebut dan dikembalikan pada areal perkebunan Pada akhir persidangan, Nenek Minah divonis hukuman percobaan penjara 1 bulan 15 hari selama proses penyidikan hingga persidangan ia telah ditahan yang membuatnya merasakan trauma yang mendalam.

Contoh kasus tersebut hanya sebagian kecil dari banyaknya praktik penegakan hukum yang terlalu legalistik dan diterapkan secara berlebihan. Nampak dari deskripsi kedua kasus tersebut di atas bahwa sesungguhnya sanksi hukum lain masih bisa diaplikasikan sebagai alternatif penyelesaiannya.

H.G de Bunt berpendapat bahwa hukum pidana dapat menjadi primum remedium jika atas perbuatanya korban atau kerugian menimbulkan dampak yang sangat besar, pelaku merupakan residivis dan kerugian tidak dapat dipulihkan ${ }^{9}$. Oleh karenanya dengan mengacu pada pendapat mengenai penggunaan sanksi hukum pidana yang dikecualikan

7 Dipna Videlia Putsanra, Fidelis Arie Sudah Bebas dari Kasus Kepemilikan Ganja, https://tirto.id/fidelis-arie-sudah-bebas-dari-kasus-kepemilikan-ganja-cAde (diakses pada 15 Januari 2021)

${ }^{8}$ Murdoko, Disparitas Penegakan Hukum Di Indonesia (Analisis Kritis Kasus Nenek Minah Dalam Perspektif Hukum Progresif), hukum.hangtuah.ac.id/index.php/perspektif/article/download/66/55, (diakses pada tanggal 16 Januari 2021)

${ }^{9}$ Romli Atmasasmita. (2010). Globalisasi dan Kejahatan Bisnis. Jakarta: Kencana Prenada Media Group. hlm. 192 
menjadi instrumen terakhir sehingga dapat dijadikan sebagai primum remedium dengan kriteria sebagai berikut: ${ }^{10}$

a. apabila sangat dibutuhkan dan hukum yang lain tidak dapat digunakan;

b. Menimbulkan korban yang sangat banyak;

c. Pelaku merupakan residivis;

d. Kerugian tidak dapat dipulihkan (irreparable);

e. Mekanisme penegakan hukum lainnya yang lebih ringan telah tiada berdaya guna atau tidak dipandang.

Namun demikian, pada prinsipnya hukum pidana sudah seharusnya ditempatkan sebagai instrumen terakhir (ultimum remedium) karena sejatinya sebagaimana pendapat Remmelink hukum pidana merupakan hukum yang tajam, paling keras diantara instrumen hukum lain yang juga memberikan kontrol terhadap tingkah laku masyarakat. Oleh karena itu, penetapan sanksi pidana harus dilakukan secara terukur dan berhati-hati karena hal itu terkait dengan kebijakan peniadaan hak konstitusional dan hak asasi manusia seorang individu dan sebagai warga negara.

Pergeseran penerapan ini tentu tidak terlepas dari aspek perumusan kebijakan hukum pidana yang terjadi pada tataran legislatif. Indonesia menerapkan kebijakan hukum pidana salah satunya dengan merumuskan norma sekaligus dengan sanksi pidana melalui undang-undang (kebijakan penalisasi). Namun sebagian besar undang-undang justru dinilai mencantumkan sanksi pidana yang tidak memiliki ukuran yang jelas dalam penentuan kriteria sanksi pidananya. Padahal menurut Sudikno Mertokusumo, hukum yang berfungsi sebagai perlindungan kepentingan manusia dalam penegakannya harus memperhatikan tiga unsur fundamental hukum, antara lain: ${ }^{11}$ Kepastian hukum (Rechtssicherheit), kemanfaatan (Zweckmassigkeit) dan keadilan (Gerechtigkeit) sehingga dalam menentukan pemberian sanksi pidana harus memperhatikan ketiga unsur fundamental hukum tersebut sebagai hakikat dari tujuan hukum. Mayoritas undang-undang yang disusun dengan merumuskan ancaman pidana meletakan hukum pidana lebih dahulu dari sanksi denda ataupun administratif dengan konstruksi dalam pasalnya, dari susunan ini nampak bahwa hukum pidana ditempatkan sebagai primum remidium, yaitu: ${ }^{12}$

a. Sanksi pidana + dan/atau + sanksi denda;

b. Sanksi pidana + atau + sanksi denda;

c. Sanksi pidana;

d. Sanksi pidana + dan + sanksi pidana.

Meski begitu terdapat salah satu UU yang memiliki konstruksi yang baik dalam merumuskan sanksi pidana dimana sanksi pidana ditempatkan sesuai prinsipnya sebagai ultimum remedium yaitu UU No. 32 Tahun 2009 tentang Perlindungan dan Pengelolaan Lingkungan Hidup. Di dalamnya mempersyaratkan agar sanksi administratif dan sanksi denda harus diterapkan terlebih dahulu, ketika kedua sanksi tersebut dinilai tidak

10 Titis Anindyajati dkk. (2015). “Konstitusionalitas Norma Sanksi Pidana sebagai Ultimum Remedium dalam Pembentukan Perundang-undangan”. Jurnal Konstitusi, Volume 12 Nomor 4, Desember 2015, hlm. 872-892 Hlm. 160.

11 Sudikno Mertokusumo. (2005). Mengenal Hukum Suatu Pengantar, Yogyakarta:Liberty.

${ }^{12}$ Titis Anindyajati dkk. Op.Cit, hlm. 879 
mampu memberikan efek jera, maka barulah sanksi pidana dapat diterapkan setelah sebelumnya perbuatan tersebut dikenai sanksi administratif maupun sanksi denda.

\section{Implikasi Penerapan Hukum Pidana Sebagai Primum Remidium}

Penerapan hukum pidana sebagai salah satu cara dalam menjalankan tugas pokok Negara dalam rangka penanggulangan kejahatan dalam rangka memberikan perlindungan bagi masyarakat disebut sebagai kebijakan kriminal. Kebijakan kriminal dapat dikategorikan menjadi dua yaitu kebijakan penal dan kebijakan non penal. ${ }^{13}$ Praktik hukum di Indonesia cenderung menggunakan kebijakan penal. Sudarto mendefiniskan kebijakan penal sebagai bentuk usaha untuk mencapai hasil perundangundangan pidana paling baik guna memenuhi syarat keadilan dan kebermanfaatan. Mengingat sifat hukum pidana yang keras jika dibandingkan sanksi hukum lainnya maka kebijakan hukum pidana diharap dapat melindungi masyarakat dengan tepat.

Kecenderungan penggunaan kebijakan penal dengan penerapan hukum pidana sebagai primum remedium dalam sistem penegakan hukum pidana di Indonesia dalam perkembangannya justru memunculkan permasalahan baru. Salah satunya adalah kelebihan kapasitas (over capacity) pada Rumah Tahanan (Rutan) dan Lembaga Pemasyarakatan (Lapas). Data BPS yang menunjukkan adanya tren penurunan angka kejahatan dalam tiga tahun terakhir, nyatanya tidak dibarengi oleh penurunan angka penahanan dan pemenjaraan. Hal ini sebagaimana tergambar pada diagram berikut: ${ }^{14}$

Diagram 1

Jumlah Narapidana dan Tahanan

Tahun 2015 s/d 2020

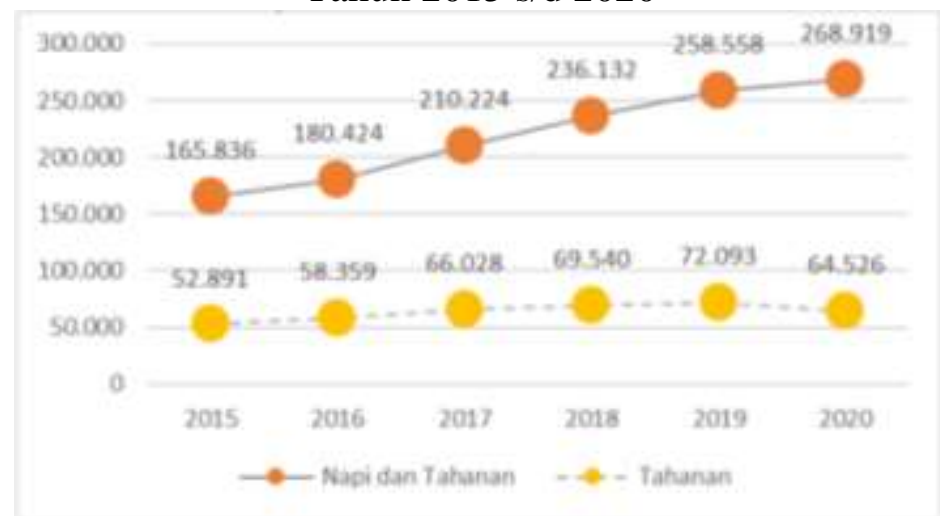

Sumber: smslap.ditjenpas.go.id yang diolah kembali oleh Iqrak Sulhin

Diagram tersebut justru menunjukan kontradiksi dengan tren penurunan jumlah rata-rata kasus kejahatan yang terjadi di Indonesia karena nampak terlihat bahwa jumlah akumulasi tahanan dan narapidana naik setiap tahunnya. Berdasarkan data pada Sistem database pemasyarakatan Kementerian Hukum dan Hak Asasi Manusia (Kemenkumham) mencatat jumlah narapidana dan tahanan di Indonesia mencapai 260.281 orang sementara kapasitas penjara hanya 131.931 orang. Sehingga terjadi

13 Evan C. (2016). Privatisasi Penjara: Upaya Mengatasi Krisis Lembaga Pemasyarakatan di Indonesia. Yogyakarta: Calpulis. hlm. 1.

14 Iqrak Sulhin. (2020). Covid-19, Pemenjaraan Berlebihan, Dan Potensi Katastrofe Kemanusiaan. Jurnal Hukum \& Pembangunan $50 \quad$ No. 2 (2020): $400-422$ Jo. http://smslap.ditjenpas.go.id/public/grl/status_pas/daily 
kelebihan kapasitas sebanyak 97\%. ${ }^{15}$ Satu ruangan sel yang berkapasitas memuat tiga hingga empat warga binaan ada yang diisi sampai sepuluh orang bahkan lebih. Hal ini tentu sangat memprihatinkan dan justru memberikan dampak negative baik bagi warga binaan maupun bagi sistem pembinaan dalam Lapas itu sendiri. Hak-hak konstitusional seorang warga binaan pun sangat berpotensi terlanggar. Keberadaan begitu banyaknya peraturan perundang-undangan yang didalamnya mencantumkan substansi ancaman sanksi pidana seolah-olah menjadi alat dan keharusan untuk bagi pelanggar hukum untuk ditempatkan di dalam Rutan maupun Lapas. Hal ini yang turut serta menjadi faktor utama kelebihan kapasitas.

Adapun beberapa dampak negatif kelebihan kapasitas Lapas antara lain sebagai berikut:

a. Fenomena kerusuhan Lapas yang berulang terjadi di berbagai wilayah di Indonesia, yang terbaru terjadi di Lapas Tuminting Manado pada April 2020 ${ }_{1 a l u^{16}}$. Kerusuhan tersebut juga disertai pembakaran yang mengakibatkan tiga blok lapas hangus terbakar, dan 100 warga binaan harus dipindahkan, satu orang napi dikabarkan terkena tembakan Petugas Lapas saat berusaha menertibkan kerusuhan;

b. Kurang maksimalnya pengawasan oleh petugas Rutan atau Lapas akibat jumlah petugas pengamanan yang tidak sebanding dengan jumlah warga binaan sehingga masih sering dijumpai adanya tindak pidana yang dikendalikan dari dalam Lapas;

c. Kesehatan warga binaan tidak terjamin akibat kelebihan penghuni pada masingmasing sel.

d. Memicu timbulnya konflik antara warga binaan.

Jimly Asshiddiqie menuturkan bahwa sesungguhnya penegakan hukum di Indonesia masih berorientasi pada penghukuman dan pembalasan belum sepenuhnya mendidik. Hal ini dapat dilihat dari keseluruhan mantan tahanan yang telah selesai menjalani masa hukuman, hanya sekitar 30 persen saja yang tidak mengulangi kesalahannya lagi. 30 persen lainnya merasakan dendam dan 40 persen semakin banyak melakukan kejahatan setelah keluar dari lapas. ${ }^{17}$

Data yang dihimpun oleh Tim BPHN, di dalam KUHP terdapat ancaman sanksi pidana penjara sebanyak 485 kali dengan rincian sebagai berikut: ${ }^{18}$

a. Kedudukan sanksi pidana penjara adalah sebagai pidana pokok, sebagai alternatif atau sebagai pidana yang bersifat sementara atau sebagai pidana pengganti.

b. Pidana penjara dengan hitungan tahun sebagai ancaman pidana pokok sebanyak 274 kali.

c. Pidana penjara dengan hitungan tahun atau seumur hidup sebanyak 292 kali.

15 Kemenkumham, http://lapassalemba.kemenkumham.go.id/informasi-publik/data-sdp/jumlahpenghuni (diakses pada tanggal 16 Januari 2021).

${ }^{16}$ Skivo Marcelino Mandey. (2020). Ada 11 Narapidana Otak Kerusuhan dan Pembakaran Lapas Tuminting Manado", https://regional.kompas.com/read/2020/04/12/11212191/ada-11-narapidana-otakkerusuhan-dan-pembakaran-lapas-tuminting-manado?page=all (diakses pada tanggal 16 Januari 2021).

${ }^{17}$ Dian Erika Nugraheny. (2020). "Jimly Sarankan Penerapan Sistem Peradilan Etika untuk Atasi Kelebihan Penghuni di Lapas". https://nasional.kompas.com/read/2020/11/11/19280911/jimly-sarankanpenerapan-sistem-peradilan-etika-untuk-atasi-kelebihan?page=all (diakses pada tanggal 16 Januari 2021).

${ }^{18}$ Mudzakkir dkk, Op.cit. hlm. 15 
d. Pidana penjara diancamkan sebagai ancaman pidana alternatif dari ancaman pidana lain sebanyak 26 kali.

Sementara pada instrument hukum di luar KUHP, terhitung sejak tahun 1998 atau awal reformasi hingga tahun 2016, terdapat sebanyak 563 peraturan perundang-undangan baru yang di dalamnya terdapat sekitar 154 peraturan perundang-undangan yang memuat aturan dan ketentuan hukum pidana dengan jumlah 1.601 jenis tindak pidana yang diancam dengan sanksi pidana penjara. ${ }^{19}$

Hukum pidana sudah seharusnya diterapkan dengan memperhatikan berbagai macam faktor agar tetap menjaga dalil ultimum remedium dan tidak terjadi over criminalization, Yenti Garnasih berpendapat pertimbangan tersebut antara lain sebagai berikut: ${ }^{20}$

a. Jangan menggunakan hukum pidana dengan secara emosional;

b. hindari menggunakan hukum pidana untuk memidana perbuatan yang tidak jelas korban atau kerugiannya;

c. Memperhatikan cost, tidak menggunakan hukum pidana apabila kerugian yang ditimbulkan lebih kecil daripada biaya pemidanaannya;

d. Jangan menggunakan hukum pidana apabila tidak didukung oleh masyarakat secara kuat;

e. Jangan menggunakan hukum pidana apabila penggunaannya diperkirakan tidak akan efektif;

f. Hukum pidana dalam hal-hal tertentu harus mempertimbangkan secara khusus skala prioritas kepentingan pengaturan;

g. Hukum pidana sebagai sarana represif harus didayagunakan secara serentak dengan sarana pencegahan.

Pada akhirnya sanksi hukum pidana tidak selalu menjadi solusi penyelesaian suatu masalah mengingat di dalamnya belum tentu mencapai pemulihan keadaan sebagaimana sebelum terjadinya tindak pidana yang dilakukan oleh Pelaku. Oleh karena itu konsep keadilan restoratif dinilai sangat penting dijadikan alternatif penyelesaian dan dalam rangka memulihkan kembali keadaan seperti semula sebelum terjadi suatu tindak pidana dan sebagai upaya menempatkan kembali hukum pidana sebagai senjata terakhir.

\section{Pendekatan Keadilan Restoratif (Restorative Justice) Sebagai Upaya Menempatkan Kembali Hukum Pidana Sebagai Ultimum Remeidium}

Hukum pidana pada hakikatnya bertujuan untuk mengatur dan memberikan perlindungan bagi tata kehidupan masyarakat. Sudarto membagi tujuan hukum pidana menjadi dua. Pertama, secara umum mengatur hidup kemasyarakatan atau untuk menyelenggarakan tata dalam masyarakat, Kedua, secara khusus melindungi kepentingan hukum terhadap perbuatan yang hendak mencederainya (rechtsguterschutz) dengan sanksi yang berupa pidana yang sifatnya lebih tajam jika dibandingkan dengan sanksi yang terdapat pada bidang hukum lainnya. Dalam sanksi pidana itu terdapat suatu tragic (suatu yang menyedihkan) sehingga hukum pidana dikatakan "mengiris

\footnotetext{
${ }^{19}$ Lampiran Peraturan Menteri Hukum Dan Hak Asasi Manusia Republik Indonesia Nomor 11 Tahun 2017 Tentang Grand Design Penanganan Overcrowded Pada Rumah Tahanan Negara Dan Lembaga Pemasyarakatan, hlm. 22

20 Yenti Garnasih. (2008). Ultimum Remedium, On LBH Pers. diunduh dari https://anggara.files.wordpress.com/2008/07/keterangan-bu-yenti.pdf (diakses pada tanggal 16 Januari 2021).
} 
dagingnya sendirie atau sebagai "pedang bermata dua" yang berarti hukum pidana memang bertujuan untuk melindungi kepentingan-kepentingan hukum (seperti nyawa, harta benda, kemerdekaan, kehormatan), namun jika terjadi penyimpangan atas penerapan hukum pidana itu sendiri maka justru melanggar hak-hak hukum si pelanggar. ${ }^{21}$ Sehingga posisi hukum pidana sebagai alat kontrol sosial adalah subsidair yaitu hendaknya baru dipergunakan apabila usaha-usaha lain kurang memadai (ultimum remedium).

Pembaharuan hukum pidana merupakan langkah yang efektif dalam upaya merubah paradigma pemidanaan yang selama ini menjalankan praktik penerapan yang primum remedium dengan dominasi penjatuhan sanksi perampasan kemerdekaan. Hingga kini upaya pembaharuan itu masih terus dilakukan salah satunya dengan perumusan Rancangan Kitab Undang-Undang Hukum Pidana (RKUHP) yang memiliki tujuan utama untuk menciptakan kodifikasi hukum pidana nasional guna menggantikan KUHP peninggalan Belanda yang dinilai sudah tidak lagi sesuai dengan nilai-nilai bangsa Indonesia. $^{22}$ Namun sayangnya jika dilihat dalam rumusan RKUHP itu sendiri tidak merubah focus perampasan kemerdekaan dalam penjatuhan sanksi. Kebijakan alternatif penjatuhan pidana denda maupun kerja social seolah belum dijadikan pertimbangan utama oleh para penyusun peraturan perundang-undangan. Padahal sejatinya pembaharuan hukum pidana harus dilakukan secara menyeluruh meliputi pembaruan hukum pidana materiil (substansi), hukum pidana formil (hukum acara pidana), dan hukum pelaksanaan atas pidana yang telah dijatuhkan.

Penggunaan konsep keadilan restoratif (restorative justice) jika diterapkan dengan benar selain dapat mencapai keadilan bagi seluruh pihak baik pelaku maupun korban, juga mampu mengembalikan hakikat hukum pidana sebagai ultimum remedium yang akan berimplikasi positif pada solusi dampak atas keadaan over kriminalisasi seperti kelebihan kapasitas di Lapas sebagaimana pembahasan pada sub bab sebelumnya. Konsep keadilan restoratif ini telah banyak diterapkan di negara-negara Eropa, Austria dan Amerika Utara. ${ }^{23}$ Andi Hamzah mengungkapkan bahwa 60\% perkara yang ditangani jaksa di Belanda diselesaikan melalui penyelesaian perkara di luar pengadilan (afdoening buiten process). Sedangkan perkara yang ada di Indonesia yang menganut Asas Legalitas, $99 \%$ pada akhirnya dilimpahkan ke pengadilan. ${ }^{24}$

Lantas apa itu keadilan restoratif? Howard Zher seorang perintis keadilan restoratif di Amerika Serikat, mengartikan keadilan restoratif sebagai suatu proses yang melibatkan pihak-pihak yang berkepentingan dari sebuah pelanggaran (Pelaku dan Korban) untuk kemudian secara bersama-sama mengidentifikasi kerugian serta memenuhi kewajiban dan kebutuhan korban sebagai hak yang harus diterima atas pelanggaran yang terjadi. ${ }^{25}$ Upaya penyembuhan antara pelaku dan korban dilakukan dengan caranya mempertemukan pelaku dalam satu forum dengan korban dan keluarganya guna

${ }^{21}$ Sudarto. (1990). Hukum Pidana I, Semarang: Yayasan Sudarto. hlm 9

22 Nyoman Serikat Putra Jaya. (2005). Relevansi Hukum Pidana Adat Dalam Pembaharuan Hukum Pidana Nasional. Bandung:PT Citra Aditya Bakti. hlm. 3.

${ }^{23}$ Eriyanto Wahid. (2009). Keadilan Restoratif dan Peradilan Konvensional dalam Hukum Pidana, Jakarta: Universitas Trisakti. hlm.1

${ }^{24}$ https://news.detik.com/kolom/d-4163780/penerapan-hukum-pidana-yang-berlebihan diakses (diakses pada tanggal 16 Januari 2021).

${ }^{25}$ Ahmad Ali. (2009). Menguak Teori Hukum (Legal Theory) dan Teori Peradilan(Judicial Prudence), Jakarta: Kencana Prenada Media, hlm. 11 
menumbuhkan empati bagi kedua belah pihak. Sehingga upaya penyelesaian konflik yang dikedepankan tidak hanya menegaskan kesalahan pelaku untuk kemudian dijatuhi sanksi pidana, namun ada pula peran aktif pihak yang berkonflik dalam hal ini korban yang sesungguhnya secara langsung mengalami kerugian atau kenestapaan dengan melalui mediasi atau konpensasi terhadap kerugian materiil dan immateriil dalam bentuk restitusi atau konpensasi dan pemulihan kehormatan hubungan kemanusiaan antar para pihak-pihak (humanisasi). ${ }^{26}$ Sebagaimana diketahui bahwa sistem peradilan pidana Indonesia kurang memberi perhatian pada kebutuhan korban karena perspektif korban dalam hukum publik yaitu adalah "negara" sedangkan posisi korban lebih banyak berperan pada proses pembuktian.

Oleh karena itu perlu dilakukan pembaharuan hukum pidana yang menunjang upaya penerapan hukum pidana sebagai ultimum remedium melalui upaya-upaya sebagai berikut, Pertama, Penerapan kebijakan dekriminalisasi pada berbagai peraturan perundang-undangan di Indonesia. Hal ini dikarenakan banyaknya jenis perbuatan yang dikategorikan sebagai suatu tindak pidana (kriminalisasi) atau dengan alternatif menjadikannya pelanggaran dalam bidang hukum lain misalnya pada kasus pencemaran nama baik tidak lagi menjadi perbuatan yang melanggar hukum pidana namun dapat diselesaikan dengan pendekatan hukum lainnya. Kedua, Reorientasi sistem hukum acara pidana yang memebrikan kemungkinan adanya proses penyelesaikan perkara pidana diluar pengadilan (afdoening buiten process).

\section{SIMPULAN}

Hukum Pidana di Indonesia yang idealnya diterapkan sebagai senjata pamungkas terakhir (ultimum remedium) dalam penanggulangan pelanggaran kini telah bergeser menjadi senjata utama (primum remedium). Hal ini tidak terlepas dari praktik politik hukum pidana yang masih berorientasi sebagai bentuk pembalasan dan penghukuman sehingga lebih mengutamakan kebijakan penal dengan fokus pejatuhan sanksi berupa perampasan kemerdekaan. Oleh karena itu sanksi hukum pidana tidak pernah absen pada setiap produk hukum yang disahkan oleh DPR dan Pemerintah. Hal ini yang menyebabkan adanya kondisi over kriminalisasi yang melahirkan masalah baru pada tataran aplikatif penegakan hukum salah satunya adalah fenomena kelebihan kapasitas pada Rutan dan Lapas hingga mencapai 97\%. Kondisi semacam ini juga menimbulkan masalah sosial baru bagi para warga binaan yang hak-hak konstitusionalnya di dalam lapas atau rutan turut terampas. Pembaharuan hukum pidana dinilai sangat mendesar dengan mengakomodasi pendekatan keadilan restorative dalam rangka menempatkan kembali hukum pidana sebagai ultimum remedium dengan cara Pertama, Penerapan kebijakan dekriminalisasi pada berbagai peraturan perundang-undangan di Indonesia. Kedua, Reorientasi sistem hukum acara pidana yang memebrikan kemungkinan adanya proses penyelesaikan perkara pidana diluar pengadilan (afdoening buiten process).

\section{DAFTAR PUSTAKA}

Ahmad Ali. (2009). Menguak Teori Hukum (Legal Theory) dan Teori Peradilan(Judicial Prudence), Jakarta: Kencana Prenada Media.

\footnotetext{
${ }^{26}$ Dewi Setyowati. (2020). Memahami Konsep Restorative Justice sebagai Upaya Sistem Peradilan Pidana Menggapai Keadilan. Jurnal Pandecta, Volume 15. No. 1. June 2020 Page 121-141
} 
Badan Pusat Statistik. (2020). Statistik Kriminal 2020, Hlm. 10 Diunduh Dari Https://Www.Bps.Go.Id/Publication/2020/11/17/0f2dfc46761281f68f11afbl/ Statistik-Kriminal-2020.Html

Dewi Setyowati. (2020). Memahami Konsep Restorative Justice sebagai Upaya Sistem Peradilan Pidana Menggapai Keadilan. Jurnal Pandecta, Volume 15. No. 1. June 2020 Page 121-141

Dian Erika Nugraheny. (2020). "Jimly Sarankan Penerapan Sistem Peradilan Etika untuk Atasi Kelebihan Penghuni di Lapas". https://nasional.kompas.com/read/2020/11/11/19280911/jimly-sarankanpenerapan-sistem-peradilan-etika-untuk-atasi-kelebihan?page=all (diakses pada tanggal 16 Januari 2021).

Dipna Videlia Putsanra, Fidelis Arie Sudah Bebas dari Kasus Kepemilikan Ganja, https://tirto.id/fidelis-arie-sudah-bebas-dari-kasus-kepemilikan-ganja-cAde (diakses pada 15 Januari 2021)

Eriyanto Wahid. (2009). Keadilan Restoratif dan Peradilan Konvensional dalam Hukum Pidana, Jakarta: Universitas Trisakti.

Evan C. (2016). Privatisasi Penjara: Upaya Mengatasi Krisis Lembaga Pemasyarakatan di Indonesia. Yogyakarta: Calpulis.

https://news.detik.com/kolom/d-4163780/penerapan-hukum-pidana-yang-berlebihan diakses (diakses pada tanggal 16 Januari 2021).

Iqrak Sulhin. (2020). Covid-19, Pemenjaraan Berlebihan, Dan Potensi Katastrofe Kemanusiaan. Jurnal Hukum \& Pembangunan 50 No. 2 (2020): 400-422 Jo. http://smslap.ditjenpas.go.id/public/grl/status_pas/daily

Kemenkumham, $\quad$ http://lapassalemba.kemenkumham.go.id/informasi-publik/datasdp/jumlah-penghuni (diakses pada tanggal 16 Januari 2021).

Lampiran Peraturan Menteri Hukum Dan Hak Asasi Manusia Republik Indonesia Nomor 11 Tahun 2017 Tentang Grand Design Penanganan Overcrowded Pada Rumah Tahanan Negara Dan Lembaga Pemasyarakatan.

Mudzakkir Dkk, Perencanaan Pembangunan Hukum Nasional Bidang Hukum Pidana Dan Sistem Pemidanaan (Politik Hukum Dan Pemidanaan), diunduh pada Https://Www.Bphn.Go.Id/Data/Documents/Pphn_Bid_Polhuk\&Pemidanaan .Pdf.

Murdoko, Disparitas Penegakan Hukum Di Indonesia (Analisis Kritis Kasus Nenek Minah Dalam Perspektif Hukum Progresif), http://perspektifhukum.hangtuah.ac.id/index.php/perspektif/article/downloa d/66/55, (diakses pada tanggal 16 Januari 2021)

Nyoman Serikat Putra Jaya. (2005). Relevansi Hukum Pidana Adat Dalam Pembaharuan Hukum Pidana Nasional. Bandung:PT Citra Aditya Bakti.

P.A.F. Lamintang. (1984). Hukum Panitensier Indonesia. Bandung: Armico, Bandung.

Romli Atmasasmita. (2010). Globalisasi dan Kejahatan Bisnis. Jakarta: Kencana Prenada Media Group. 
Skivo Marcelino Mandey. (2020). Ada 11 Narapidana Otak Kerusuhan dan Pembakaran Lapas Tuminting Manado", https://regional.kompas.com/read/2020/04/12/11212191/ada-11-narapidanaotak-kerusuhan-dan-pembakaran-lapas-tuminting-manado?page=all (diakses pada tanggal 16 Januari 2021).

Sudarto. (1990). Hukum Pidana I, Semarang: Yayasan Sudarto.

Sudikno Mertokusumo. (2005). Mengenal Hukum Suatu Pengantar, Yogyakarta:Liberty. Hlm.160.

Teguh Prasetyo. (2010). Hukum Pidana. Jakarta: Rajawali Press.

Titis Anindyajati dkk. (2015). "Konstitusionalitas Norma Sanksi Pidana sebagai Ultimum Remedium dalam Pembentukan Perundang-undangan”. Jurnal Konstitusi, Volume 12 Nomor 4, Desember 2015.

Tolib Setiady. (2010). Pokok-Pokok Hukum Panitensier Indonesia. Bandung; Alfabeta. hlm. 19

Wirjono Prodjodikoro. (2003). Asas-Asas Hukum Pidana Di Indonesia", Bandung: Refika Aditama.

Yenti Garnasih. (2008). Ultimum Remedium, On LBH Pers. diunduh dari https://anggara.files.wordpress.com/2008/07/keterangan-bu-yenti.pdf (diakses pada tanggal 16 Januari 2021).

\section{Peraturan Perundang-Undangan}

- Undang-Undang Dasar 1945

- Kitab Undang-Undang Hukum Pidana

- Undang-Undang No. 32 Tahun 2009 tentang tentang Perlindungan dan Pengelolaan Lingkungan Hidup.

- Peraturan Menteri Hukum Dan Hak Asasi Manusia Republik Indonesia Nomor 11 Tahun 2017 Tentang Grand Design Penanganan Overcrowded Pada Rumah Tahanan Negara Dan Lembaga Pemasyarakatan. 